American Journal of Applied Sciences 8 (9): 884-892, 2011

ISSN 1546-9239

(C) 2011 Science Publications

\title{
On Becoming an Entrepreneurial Leader: A Focus on the Impacts of University Entrepreneurship Programs
}

\author{
Afsaneh Bagheri and Zaidatol Akmaliah Lope Pihie \\ Department of Science and Technical Education, Faculty of Educational Studies, \\ University Putra Malaysia, Malaysia
}

\begin{abstract}
Problem statement: Despite the significant influences of university entrepreneurship programs in developing students' entrepreneurial intention and abilities, there is little knowledge about how such programs shape students' abilities to successfully lead entrepreneurial activities. Approach: The main purpose of this qualitative study was to explore the impacts of university entrepreneurship programs in developing students' entrepreneurial leadership competencies. A sample of 14 undergraduate entrepreneurial leaders defined as having been highly involved in leading university entrepreneurship clubs and activities for at least two semesters was purposefully selected and interviewed. Results: Analysis of the data illustrated the prominent impacts of university entrepreneurship programs in developing students' entrepreneurial leadership through improving their self-awareness, self-efficacy and entrepreneurial leadership identity realization. Conclusion: It seems crucial to provide opportunities for them to explore their potentials in entrepreneurial leadership and university entrepreneurship programs may need to organize entrepreneurship clubs and associations where the students can experience leadership position and practice real roles and tasks of the leader in entrepreneurial activities. Implication of the findings for entrepreneurial leadership theory development and entrepreneurship education and the areas for future research are discussed.
\end{abstract}

Key words: Entrepreneurship, entrepreneurial leadership, entrepreneurship education, university students, developing student, co-curriculum activities, self-awareness, developing countries, solving problems

\section{INTRODUCTION}

New millennium is called the century of entrepreneurial revolution due to the numerous impacts of entrepreneurship on personal, organizational and socioeconomic development of nations (Kuratko, 2009; 2007; Murphy et al., 2006). This turned entrepreneurship education to one of the top priorities of universities and researches both in developed and developing countries (Matlay, 2006; 2005; Busenitz et al., 2003; Mueller and Thomas, 2001). Accordingly, an increasing number of higher education institutions all over the world are offering students entrepreneurship education programs and trainings (Hannon, 2006; Heinonen and Poikkijoki, 2006; Klein and Bullock, 2006; Kuratko, 2005) and enormous research efforts have been directed to assessing the impacts of entrepreneurship education on developing students' entrepreneurial intention and capabilities (Oosterbeek $e t$ al., 2010; Pittaway et al., 2009; Kundu and Rani, 2008; Pittaway and Cope, 2007a; Collins et al., 2004; Collins and Robertson, 2003). The majority of these researches found significant relationship between entrepreneurship education programs and students' intention to become an entrepreneur (Gupta et al., 2009; Guerrero et al., 2008; De Pillis and Reardon, 2007; Souitaris et al., 2007; Fayolle et al., 2006; Zhao et al., 2005) and their capabilities of creating new ventures (Hamidi et al., 2008; Ko and Butler, 2007; Wilson et al., 2007; Cox et al., 2009). However, there is little knowledge on how entrepreneurship education programs shape students' entrepreneurial capabilities and specifically entrepreneurial leadership competencies (Okudan and Rzasa, 2006). Researchers highlighted the prominent role of higher education in developing individuals' abilities to lead entrepreneurial ventures and identified the urgent need for deeper understanding of "leadership preparedness" that prospective entrepreneurs such as university students bring to the process of new venture creation (Kempster and Cope, 2010). In response, this study attempted to narrow the gaps in knowledge and empirical studies on the impacts of university entrepreneurship programs in developing students' entrepreneurial leadership.

Corresponding Author: Afsaneh Bagheri, Department of Science and Technical Education, Faculty of Educational Studies, University Putra Malaysia, Malaysia 
Am. J. Applied Sci., 8 (9): 884-892, 2011

This study is organized in six main sections. First, a review of the literature on the effects of entrepreneurship education in developing students' entrepreneurial intentions and capabilities is presented. Then, conceptual definition and importance of specific leadership competencies for success of entrepreneurial activities are discussed. Next sections are devoted to research methods and results. Finally, discussion of the findings and implications for entrepreneurial leadership theory and education development are proposed.

Entrepreneurship education and entrepreneurial intention and capability development: Despite the extensive development of entrepreneurship education, there is no consensus among entrepreneurship scholars on definition and theoretical foundation of the concept (Heinonen, 2007; Hannon, 2006). In effect, there is an ongoing debate among scholars and educators on whether or not education is needed to become an entrepreneur and if entrepreneurship education can develop the capabilities in students to create their own businesses (Klein and Bullock, 2006; Anderson and Jack, 2008; Fiet, 2000; Henry et al., 2005). A review of the studies assessing the impacts of entrepreneurship education on improving students' motivation and intention to become entrepreneurs indicates inconsistency among research findings. While enormous researches revealed the significant association between entrepreneurship education and students' intention to become entrepreneurs in a period of time after graduation (Guerrero et al., 2008; Souitaris et al., 2007; Fayolle et al., 2006), the results of recent studies showed that compulsory entrepreneurship education failed to improve students' motivation and intention to become entrepreneurs (Oosterbeek et al., 2010). Therefore, entrepreneurship scholars questioned the effectiveness of entrepreneurship education in motivating students and enhancing their capabilities to step-into new venture creation (Fuchs et al., 2008). Moreover, many questions were raised on how entrepreneurship education develops students' entrepreneurial leadership competencies (Okudan and Rzasa, 2006).

Entrepreneurship scholars argue that even if all students may not intend to or do not have the capabilities to become an entrepreneur, entrepreneurship education has profound effects on them through enabling them to effectively perform their tasks as an employee leading entrepreneurial activities in established organizations (Hynes and Richardson, 2007; Hytti and O'Gorman, 2004). In fact, entrepreneurship education improves students' selfawareness of their entrepreneurial abilities; the understanding of existence of entrepreneurial qualities as well as the strengths and weaknesses in abilities to involve in entrepreneurial activities (Pittaway and Cope, 2007b; Hannon, 2006; Heinonen and Poikkijoki,
2006). Entrepreneurial self-awareness changes students' perceptions about their entrepreneurial capabilities and their perspectives about their future professional life (Fayolle and Gailly, 2008). Recognizing entrepreneurial talent and potential also enables students to learn and develop their entrepreneurial knowledge and skills (Rae and Carswell, 2000). This awareness empowers students to explore their entrepreneurial abilities and enhances their entrepreneurial creativity (Fuchs et al., 2008). It also improves students' attitude and intention to create a new venture (Matlay, 2006; Souitaris et al., 2007; Smith et al., 2006).

Furthermore, entrepreneurship education improves students' entrepreneurial self-efficacy; the strong beliefs toward abilities to launch a new business in many ways (Fayolle et al., 2006; Zhao et al., 2005; Chen et al., 1998). Developing a business plan and running a small business help students experience mastery in different roles and tasks of an entrepreneur. Case studies about lifestyle and work style of entrepreneurs and working with an entrepreneur in conducting a course project change students' perceptions toward their capabilities. Finally, highlighting the merits and values of entrepreneurship for students and encouraging and supporting them to start-up their own businesses socially persuade them to engage in entrepreneurial activities (Fayolle et al., 2006; Zhao et al., 2005; Cox et al., 2009; Smith et al., 2006; Chen et al., 1998). Numerous researches have been conducted to examine the relationship between entrepreneurship education and students' self-efficacy to launch a new business. Interestingly, researchers measured the impacts of entrepreneurship education programs on students' entrepreneurial intention considering selfefficacy as a moderating factor and by asking students if the programs enable them in "becoming a leader", "solving problems", "making decisions", "being creative" and "getting people to agree with them" most of which are attributes related to entrepreneurial leadership (Wilson et al., 2007). Therefore, the findings might indicate that entrepreneurial education influences students' intention to become an entrepreneur through enhancing their self-efficacy in entrepreneurial leadership. However, few researches focused on the impacts of entrepreneurship education programs on developing students' entrepreneurial leadership competencies (Okudan and Rzasa, 2006).

Entrepreneurial leadership definition and importance: Entrepreneurial leadership is a relatively emergent paradigm of research and practice in both entrepreneurship and leadership literature. Extensive similarities between entrepreneurship and leadership disciplines in terms of historical evolution, construct definition and research methods led scholars to merge 
them into a new construct: "Entrepreneurial leadership". Entrepreneurial leadership presents novel properties that are not apparent in either of the separate components and creates a synergy that helps development of theory and practice in the two schools of thought. By definition, entrepreneurial leadership is a form of leadership distinctive from other types of leadership which enables entrepreneurs and leaders to cope with highly turbulent and competitive environments (Gupta et al., 2004). Therefore, entrepreneurial leaders have specific personal and functional competencies that empower them to successfully lead entrepreneurial endeavors either in their own new venture or in established organizations (Gupta et al., 2004; Swiercz and Lydon, 2002). Of all the personal characteristics identified for entrepreneurial leaders, proactiveness, innovativeness and risk taking are the most cited in the literature (Chen, 2007; Surie and Ashley, 2008; Gupta et al., 2004; Kuratko, 2007). Proactiveness refers to the typical ability of entrepreneurial leaders in creating and leading the future rather than waiting to be influenced by it (Zampetakis, 2008; Kickul and Gundry, 2002). Entrepreneurial innovativeness is the tendency and ability of entrepreneurial leaders in developing novel and useful ideas for recognizing entrepreneurial opportunities, utilizing resources and solving problems (Okudan and Rzasa, 2006; Chen et al., 1998; Gupta et al., 2004). Finally, risk taking reflects the propensity and ability of entrepreneurial leaders to take calculated risks in leading entrepreneurial activities and taking the responsibility for the future (Okudan and Rzasa, 2006; Chen et al., 1998; Gupta et al., 2004).

In addition to personal competencies, entrepreneurial leaders need to possess specific functional competencies which enable them to successfully perform the roles and tasks of the leader in entrepreneurial activities. There is no consensus among entrepreneurship scholars on functional competencies of entrepreneurial leaders. While some researchers identified operations, finance, marketing and human resource management as functional competencies of entrepreneurial leaders (Swiercz and Lydon, 2002), others considered building commitment among followers and specifying limitations as the particular abilities of entrepreneurial leaders (Gupta et al., 2004). Despite the debates on attributes of entrepreneurial leaders, the majority of research findings indicate the critical importance and necessity of entrepreneurial leadership competencies in new venture creation, performance and success (Sambasivan et al., 2009; Baron, 2007). However, there is little information about the capabilities enabling individuals to successfully lead entrepreneurial endeavors (Okudan and Rzasa, 2006; Gupta et al., 2004). Entrepreneurial leadership scholars emphasize "it is vital that further research delves deeper into the varying levels of leadership preparedness" that nascent entrepreneurs bring to new venture creation (Kempster and Cope, 2010). More importantly, entrepreneurial leadership research suffers from lack of in-depth studies on the impacts of entrepreneurship education programs in developing university students' entrepreneurial leadership (Okudan and Rzasa, 2006). In response, this study aimed to provide deeper insights on the impacts of entrepreneurship education on developing university students' entrepreneurial leadership.

\section{MATERIALS AND METHODS}

Entrepreneurship researchers emphasized the urgent need for employing qualitative research methods to gain a rich understanding of leadership learning and development that occurs as a result of students' engagement in university entrepreneurship programs (Conger, 2004). However, "both leadership and entrepreneurship have been dominated by quantitative techniques" (Kempster and Cope, 2010). By employing a qualitative research method, this study intended to gain deeper insights of the impacts of university entrepreneurship programs on developing students' entrepreneurial leadership.

Participants: A sample of 14 student entrepreneurial leaders defined as undergraduates who were highly active in leading university entrepreneurship clubs and activities for at least two semesters involved in this study. The sample size of fourteen students reflects understanding and repetition of the dominant impacts of university entrepreneurship programs on developing students' entrepreneurial leadership (Mason, 2002). The rationale behind utilizing undergraduates as the participants of this study was that compared to other university students, undergraduates are the most interested students in entrepreneurship and are most likely to create their own ventures (Mueller and Thomas, 2001; Gupta et al., 2009; Harris and Gibson, 2008; Wu and $\mathrm{Wu}, 2008)$. Therefore, developing their entrepreneurial leadership competencies assist them in successfully leading entrepreneurial activities in their future careers. The criterion for choosing student entrepreneurial leaders was that they were holding the leadership position of university entrepreneurship clubs and activities for at least two semesters. This criterion ensured that the students had profound experiences in leading entrepreneurial activities (Patton, 2002). The 
student entrepreneurial leaders were selected from two public and two private universities in central zone of Malaysia to include the diversity of the students and entrepreneurship programs across the universities (Matlay, 2006). All of the universities offered students with entrepreneurship programs both in their curriculum and co-curriculum activities.

Illustrates background information of the participants. Of all the students, nine were holding the leadership position of university entrepreneurship clubs and activities for more than three semesters. The majority of participants had different education backgrounds including Computer Science, IT business, Business Administration, Creative Multimedia, Landscape Architecture and Telecommunication Engineering. The average age of the students was 22 years. Of the fourteen students, two were female and the rest were male. Eight of the students were from public universities and six students were from private universities.

Data collection and data analysis: Individual semistructured interviews were conducted at the participants' universities and focused on the impacts of university entrepreneurship programs on developing students' competencies of leading entrepreneurial clubs and activities. A list of questions was developed based on the literature review including but not limited to: "How did university entrepreneurship programs help you develop your leadership skills?", "What competencies did you develop leading the university entrepreneurship projects?" and "What were the most influential factors affecting your leadership development?" This list was given to an "expert panel" consisting of three local university entrepreneurship and qualitative research lecturers to ensure the content validity of the questions. The interviews lasted between 50-110 min and were recorded on a digital audio recorder and transcribed verbatim within 48 hours of the actual interview.

Data analysis was performed through two main procedures (Grbich, 2007). First, "preliminary data analysis" was carried out after each interview was conducted through reading over and over the transcribed interview to investigate the emerging issues, potential themes, gaps in data and future research directions. Second, "thematic analysis" was performed by reducing data to manageable and meaningful groups, categories and themes based on research questions. This phase of data analysis was carried out once all of the interviews had been conducted and focused on identifying the categories and themes in relation to the impacts of university entrepreneurship programs in developing entrepreneurial leadership among students.
The trustworthiness of the research findings was ensured through employing several techniques. First, detailed transcriptions and field notes were provided and the findings were checked against biasness by presenting the codes, themes and findings to some of our colleagues involving in entrepreneurship research (Bogden and Biklen, 2003). Moreover, students who were highly involved in leading university entrepreneurship clubs and activities were selected through the university entrepreneurship program coordinators and their friends to address the biases in participants' selection and avoiding selection of those students who just have the leadership positions but are not fully involved in leading the entrepreneurship projects. Furthermore, data were triangulated by member checking with participants (sending the transcribed interviews to the students for content validity confirmation) and peer reviewing (presenting the findings to a group of entrepreneurship researchers) for avoiding any biases (Creswell, 2007). The results of the data analysis and the emerging themes are detailed in the following sections.

\section{RESULTS}

Analysis of the data indicated three dominant themes in relation to the impacts of university entrepreneurship programs in developing the students' competencies to lead entrepreneurial activities which are: Improving students' entrepreneurial leadership self-awareness, self-efficacy and identity realization.

Self-awareness improvement: A majority of the student entrepreneurial leaders highlighted the great impact of university entrepreneurship programs and practicing leadership skills on helping them explore their capability of leading entrepreneurial activities and their leadership weaknesses. For example, Zakaria emphasized that leading the university entrepreneurship projects was the first time he understood that he has the ability to lead entrepreneurial activities "Here was the first time I realized [that] I can lead a business project [and] I can complete the objectives." Eza also explained the impact of leading university entrepreneurship club in recognizing the existence of the capabilities of leading an entrepreneurial team "Now I can actually see [that] I can be the leader and [I] can also lead a team...to do entrepreneurial activities."

Importantly, leading university entrepreneurship clubs and activities had a prominent influence on making Farhad aware of his weaknesses in his leadership skills specifically, lack of effective communication kills and ability to influence his group members to understand the objectives of the entrepreneurial project: 
Am. J. Applied Sci., 8 (9): 884-892, 2011

Leading the projects actually made me realize that I am not perfect...but I need to learn. I have to understand all the values of the team members... and make sure that everybody understands the end objective of the project...I [need to] learn on listening and understanding of the other people's problems

Hisyam highlighted the influential impact of leading university entrepreneurial projects on enhancing his awareness about the capabilities he needs to improve in order to successfully lead entrepreneurial activities:

Right now I handle one club...it is like now [it] makes me read myself. I can read my level. After one year I can see how far I could make this club to go. I can measure my abilities from that and which one I [should] improve

Leading university entrepreneurship clubs and projects helped student entrepreneurial leaders become aware of their potential in leading entrepreneurial activities, their leadership weaknesses and the skills they need to improve.

Self-efficacy improvement: Student entrepreneurial leaders also highlighted the influential impacts of university entrepreneurship programs in enhancing their entrepreneurial leadership self-efficacy. That means the programs changed their perceptions towards their capabilities to lead entrepreneurial activities, improved their confidence in their entrepreneurial leadership capabilities and enhanced their perseverance in coping with the challenges and problems associated with entrepreneurial activities. Zakaria noted the role of leading university entrepreneurship club and activities in shaping a strong perception toward his ability to lead entrepreneurial venturing "I joined leading these activities and I learned everything. I think I feel like I want to stop my studies and start my [own] business." In explaining his abilities to lead entrepreneurial venturing, Ariif stressed the role of leading the university entrepreneurship club in improving his confidence in his leadership capabilities:

Before joining these activities actually...I didn't interact with people. After I joined leading this club I got more confidence [in]... how to talk to other people. I know how to handle the cooperate business. I know how to conduct my own people, how to give tasks to the people and how to lead them to do the tasks... [and] how to handle the problems
Moreover, leading university entrepreneurship clubs and projects played a critical role in enhancing student entrepreneurial leaders' persistence in facing the challenges and problems involved in leading entrepreneurial activities as Ariif further asserted:

If the project doesn't work, it doesn't mean that I have to stop there. There are still people who are willing to do it. If I start with only two [people], I can convince the other two to do it. So I can convince the others as well. If the current members are not interested I don't give up. I can find other people...to help us

In response to the question that how university entrepreneurship programs helped him develop his leadership skills, Farhad also highlighted the influence of the programs in improving his perseverance in learning how to face the challenges of entrepreneurial activities "It actually made me work harder and study harder on entrepreneurship. For example, if I don't know something, I will... get as much as knowledge I can. So next time if [I] face the problem...I would know about it."

Entrepreneurial leadership identity realization: An emerging theme in examination of the data was the important role that university entrepreneurship programs played in giving the students the identity of the leader in entrepreneurial activities. That means all of the student entrepreneurial leaders recognized themselves as the leader of the university entrepreneurship projects and activities who is expected to play the roles and tasks of the leader and is responsible for the performance and outcomes of the team. This leadership identity realization helped the student entrepreneurial leaders learn and develop their entrepreneurial leadership through enacting leadership and being committed to the objectives of the entrepreneurial projects and activities, though the majority of them voluntarily joined leading the activities. For example, Ariif recognized himself as the leader of university entrepreneurial project who has the responsibility for successfully achieving its objectives "In [this] club, I am the organizer of the events. I took the responsibility and have to do everything myself to make it perfect. I am the person [who] has to figure out [how to] go forward [and] finish it." Interestingly, Hisyam differentiated between himself and his followers in terms of his higher responsibility in decision making and identified himself as the leader of the group having the responsibility to construct the club: 
The difference between the leader and follower is [in] decision making. Because decision making is up to me. It's not the followers that make the decisions. So, my responsibility is higher...I know that I am the person [who]...need to fix all [the] foundation. I need to fix all the club. I need to maintain my club

Hisyam replied to a follow-up question that how this recognition of leadership responsibilities helped him develop his leadership as: "it helped me a lot [in] that I had to find [out] how to lead, how to conduct people. It made me learn about leadership." Furthermore, leading the university entrepreneurship clubs and projects enhanced student entrepreneurial leaders' awareness that in the world of entrepreneurship they cannot work alone and they need to combine their group members' knowledge and skills to successfully achieve the goals. This is evident in Zakaria's comment:

If I do it alone maybe [I] cannot. But [I] can do the business in a group... because working alone first has a lot of stress. Second, I don't have the time to manage. Because everything I need to do alone. Because when we start by grouping, for example, I graduate from computer science. My friend also graduated from engineering. We start [the] business with five people. We can combine, we make much more profit. We are not alone

\section{DISCUSSION}

Despite the vast expansion of entrepreneurship education programs all over the world, there is little knowledge on how these programs develop students' entrepreneurial capabilities and specifically their entrepreneurial leadership. The findings of this study highlighted the influential impacts of university entrepreneurship programs on enhancing students' awareness about their entrepreneurial leadership abilities and entrepreneurial self-efficacy as well as entrepreneurial leadership identity realization. More specifically, the programs played a prominent role in students' awareness of their competencies to lead entrepreneurial activities, their weaknesses in leadership skills and the leadership areas they required to improve. Due to the critical importance of awareness in developing students' entrepreneurial behavior, it seems crucial to provide opportunities for them to explore their potentials in entrepreneurial leadership (Souitaris et al., 2007). The findings of this study supported the significant role of involving students in entrepreneurship clubs and associations in developing their entrepreneurial capabilities (Fayolle and Gailly, 2008; Okudan and Rzasa, 2006; Fuchs et al., 2008). Particularly, this study showed the influential role of leading university entrepreneurship clubs and activities in developing students' entrepreneurial leadership.

Furthermore, the findings of this study indicate the influential role that university entrepreneurship programs play in improving students' entrepreneurial leadership self-efficacy; a strong belief in their competencies to successfully lead entrepreneurial activities and facing the challenges and problems associated with leadership in an entrepreneurial context. Although the importance of university entrepreneurship programs in developing students' entrepreneurial selfefficacy has been documented by previous researches (Fayolle et al., 2006; Wilson et al., 2007; Zhao et al., 2005; Segal et al., 2005), the findings of this study indicate the influential impact of the programs in improving students' entrepreneurial leadership selfefficacy. This necessitates providing more purposeful entrepreneurship programs in order to improve students' entrepreneurial leadership self-efficacy if we are to improve the number and quality of future entrepreneurial leaders (Chen et al., 1998).

This study also revealed the critical contributions of university entrepreneurship programs in developing students' entrepreneurial leadership through realizing their entrepreneurial leadership identity. This is in sharp contrast to the research findings that entrepreneurs were not aspired to play the roles of the leader and did not identified themselves as the leader of their entrepreneurial ventures (Kempster and Cope, 2010). In fact, university entrepreneurship programs provided the opportunity for students to perform the real tasks and roles of the leader in entrepreneurial clubs and projects where they were appointed to the leadership position and were aspired and identified as the leader of entrepreneurial activities who was expected to play the roles and tasks of the leader and was responsible for the success and failure of the group. Accordingly, university entrepreneurship programs may need to organize entrepreneurship clubs and associations where the students can experience leadership position and practice real roles and tasks of the leader in entrepreneurial activities (Fuchs et al., 2008; Fayolle et al., 2006; Wayne et al., 2008). Student entrepreneurial leadership identity and the significant role of university entrepreneurship programs in students' entrepreneurial leadership identity realization is an emergent theme from this study. This may assist entrepreneurship educators in developing specific programs to improve students' entrepreneurial leadership identity and thereby develop their entrepreneurial leadership 
competencies. It may also help entrepreneurship scholars develop a theory on students' entrepreneurial leadership development by considering identity as one of the factors affecting entrepreneurial leadership development.

The findings of the current study provide deeper insights on university students' entrepreneurial leadership development through identifying the impacts of the university entrepreneurship programs on developing students' competencies of leading entrepreneurial activities. However, the limitation of the findings in terms of generalizability to other contexts should be noted. Due to the qualitative research approach employed in this study, the data is highly contextual and findings should be limited to students who are involved in leading university entrepreneurship clubs and activities in the setting covered by purposive sampling. To buffer this limitation, however, the participants were selected from both public and private universities and different education backgrounds.

\section{CONCLUSION}

There is an ongoing debate on the impacts of university entrepreneurship programs in developing students' entrepreneurial leadership and necessity of providing specific education program for developing students' entrepreneurial leadership competencies (Okudan and Rzasa, 2006). This lack of knowledge affects the design, content and pedagogical methods of entrepreneurial leadership education programs and courses (Okudan and Rzasa, 2006; Henry et al., 2005). The main purpose of this study was to provide deeper knowledge and understanding of the impacts of university entrepreneurship programs in developing students' entrepreneurial leadership. The findings revealed profound influences of university entrepreneurship programs in improving university students' entrepreneurial leadership through enhancing their entrepreneurial leadership self-awareness, selfefficacy and identity realization. The findings contribute to the growing body of literature on entrepreneurial leadership learning and development (Kempster and Cope, 2010). However, future research with larger sample sizes and more diverse samples need to be undertaken to examine the contributions of entrepreneurship education programs in developing entrepreneurial leadership competencies of students. Student entrepreneurial leadership identity and influential role of university entrepreneurship programs in students' entrepreneurial leadership identity realization emerging from this study has a great potential for further investigations. Future studies can also be done on the process through which students' entrepreneurial leadership identity develops and factors affecting development of their entrepreneurial leadership identity.

\section{REFERENCES}

Anderson, A.R. and S.L. Jack, 2008. Role typologies for enterprising education: The professional artisan? J. Small Bus. Enterprise Dev., 15: 256273. DOI: $10.1108 / 14626000810871664$

Baron, R.A., 2007. Opportunity recognition as pattern recognition: how entrepreneurs "connect the dots" to identify new business opportunities. acad. manage. perspectives, 20: 104-119.

Bogden, R. and S.K. Biklen, 2003. Qualitative Research for Education: An Introduction to Theories and Methods. 4th Edn., Allyn and Bacon, Boston, ISBN-10: 0205375561, pp: 291.

Busenitz, L.W., G.P. West, D. Shepherd, T. Nelson and G.N. Chandler et al., 2003. Entrepreneurship research in emergence: Past trends and future directions. J. Manage., 29: 285-308. DOI: 10.1016/S0149-2063_03_00013-8

Chen, C.C., P.G. Greene and A. Crick, 1998. Does entrepreneurial self-efficacy distinguish entrepreneurs from managers? J. Bus. Venturing, 13: 295-316. DOI: 10.1016/S0883-9026(97)00029-3

Chen, M.H., 2007. Entrepreneurial leadership and new ventures: Creativity in entrepreneurial teams. Creativity Innovation Manage., 16: 239-249. DOI: 10.1111/j.1467-8691.2007.00439.x

Collins, A. and M. Robertson, 2003. The entrepreneurial summer school as a successful model for teaching. Education + Training, 45: 324330. DOI: $10.1108 / 00400910310495978$

Collins, L., P.D. Hannon and A. Smith, 2004. Enacting entrepreneurial intent: The gaps between student needs and higher education capability. Education + Training, 46: 454-463. DOI: $10.1108 / 00400910410569579$

Conger, J.A., 2004. Developing leadership capability: What's inside the black box? Acad. Manage. Exec., 18: 136-140.

Cox, L.W., S.L. Mueller and S.E. Moss, 2009. The impact of entrepreneurship education on entrepreneurial self-efficacy. Int. J. Entrepreneurship Educ.

Creswell, J.W., 2007. Qualitative Inquiry and Research Design: Choosing Among Five Approaches. 2nd Edn., Choosing Among Five Approaches. Sage Publications, Thousand Oaks, CA., ISBN-10: 1412916070, pp: 395. 
De Pillis, E. and K.K. Reardon, 2007. The influence of personality traits and persuasive messages on entrepreneurial intention: A cross-cultural comparison. Career Dev. Int., 12: 382-396. DOI: $10.1108 / 13620430710756762$

Fayolle, A. and B. Gailly, 2008. From craft to science: Teaching models and learning processes in entrepreneurship education. J. Eur. Ind. Training, 32: 569-593. DOI: 10.1108/03090590810899838

Fayolle, A., B. Gailly and N. Lassas-Clerc, 2006. Assessing the impact of entrepreneurship education programmes: A new methodology. J. Eur. Ind. Training, 30: 701-720. DOI: $10.1108 / 03090590610715022$

Fiet, J.O., 2000. The pedagogical side of entrepreneurship theory. J. Bus. Ventur., 16: 101117. DOI: $10.1016 /$ S0883-9026(99)00042-7

Fuchs, K., A. Werner and F. Wallau, 2008. Entrepreneurship education in Germany and Sweden: What role do different school systems play? J. Small Bus. Enterprise Dev., 15: 365-381. DOI: 10.1108/14626000810871736

Grbich, C., 2007. Qualitative Data Analysis: An Introduction. 1st Edn., Sage Publications, London, ISBN-10: 1412921422, pp: 258.

Guerrero, M., J. Rialp and D. Urbano, 2008. The impact of desirability and feasibility on entrepreneurial intentions: A structural equation model. Int. Entrepreneurship Manage. J., 4: 35-50. DOI: 10.1007/s11365-006-0032-x

Gupta, V., I.C. MacMillan and G. Surie, 2004. Entrepreneurial leadership: Developing and measuring a cross-cultural construct. J. Bus. Ventur., 19: 241-260. DOI: 10.1016/S08839026(03)00040-5

Gupta, V.K., D.B. Turban, S.A. Wasti and A. Sikdar, 2009. The role of gender stereotypes in perceptions of entrepreneurs and intentions to become an entrepreneur. Entrepreneurship Theory Practice, 33: 397-417. DOI:10.1111/j.15406520.2009.00296.x

Hamidi, D.Y., K. Wennberg and H. Berglund, 2008. Creativity in entrepreneurship education. J. Small Bus. Enterprise Dev., 15: 304-320. DOI: 10.1108/14626000810871691

Hannon, P.D., 2006. Teaching pigeons to dance: Sense and meaning in entrepreneurship education. Education + Training, 48: 296-308. DOI: 10.1108/00400910610677018

Harris, M.L. and S.G. Gibson, 2008. Examining the entrepreneurial attitudes of US business students. Education + Training, 50: 568-581. DOI: $10.1108 / 00400910810909036$
Heinonen, J. and S.A., Poikkijoki, 2006. An entrepreneurial-directed approach to entrepreneurship education: Mission impossible? J. Manage. Dev., 25: 80-94. DOI: $10.1108 / 02621710610637981$

Heinonen, J., 2007. An entrepreneurial-directed approach to teaching corporate entrepreneurship at university level. Education + Training, 49: 310324. DOI: 10.1108/00400910710754453

Henry, C., F. Hill and C. Leitch, 2005. Entrepreneurship education and training: Can entrepreneurship be taught? Education + Training, 47: 158-169. DOI: 10.1108/00400910510592211

Hynes, B. and I. Richardson, 2007. Entrepreneurship education: A mechanism for engaging and exchanging with the small business sector. Education + Training, 49: 732-744. DOI: 10.1108/00400910710834120

Hytti, U. and C. O'Gorman, 2004. What is "enterprise education"? An analysis of the objectives and methods of enterprise education programs in four European countries. Education + Training, 46: 1123. DOI: $10.1108 / 00400910410518188$

Kempster, S. and J. Cope, 2010. Learning to lead in the entrepreneurial context. J. Entrepreneurial Behav. Res., 16: 5-34. DOI: 10.1108/13552551011020054

Kickul, J. and L. Gundry, 2002. Prospecting for strategic advantage: The proactive entrepreneurial personality and small firm innovation. J. Small Bus. Manage., 40: 85-97. DOI: 10.1111/1540627X.00042

Klein, P.G. and J.B. Bullock, 2006. Can entrepreneurship be taught? J. Agric. Appl. Econ.

Ko, S. and J.E. Butler, 2007. Creativity: A key link to entrepreneurial behaviour. Bus. Horizons, 50: 365372. DOI: 10.1016/J.BUSHOR.2007.03.002

Kundu, S.C. and S. Rani, 2008. Human resources' entrepreneurial attitude orientation by gender and background: A study of Indian Air Force trainees. Int. J. Manage. Enterprise Dev., 5: 77-101. DOI: 10.1504/IJMED.2008.015908

Kuratko, D.F., 2005. The emergence of entrepreneurship education: Development, trends and challenges. Entrepreneurship Theory Practice, 29: 577-597. DOI: $10.1111 /$ j.15406520.2005.00099.x

Kuratko, D.F., 2007. Entrepreneurial leadership in the 21st century: Guest Editor's perspective. J. Leaders. Organ. Stud., 13: 1-11. DOI: 10.1177/10717919070130040201

Kuratko, D.F., 2009. The entrepreneurial imperative of the 21st century. Bus. Horizons, 52: 421-428. 
Mason, J., 2002. Qualitative Researching. 2nd Edn., Sage Publications, London, ISBN-10: 0761974288, pp: 223.

Matlay, H., 2005. Researching entrepreneurship and education: Part 1: What is entrepreneurship and does it matter? Education + Training, 47: 665-677. DOI: 10.1108/00400910510633198

Matlay, H., 2006. Researching entrepreneurship and education: Part 2: What is entrepreneurship education and does it matter? Education + Training, 48: 704-718. DOI: 10.1108/00400910610710119

Mueller, S.L. and A.S. Thomas, 2001. Culture and entrepreneurial potential: A nine country study of locus of control and innovativeness. J. Bus. Ventur., 16: 51-75. DOI: 10.1016/S08839026(99)00039-7

Murphy, P.J., J. Liao and H.P. Welsch, 2006. A conceptual history of entrepreneurial thought. J. Manage. History, 12: 12-35. DOI: $10.1108 / 13552520610638256$

Okudan, G.E. and S.E. Rzasa, 2006. A project-based approach to entrepreneurial leadership education. Technovation, 26: 195-210. DOI: 10.1016/J.TECHNOVATION.2004.10.012

Oosterbeek, H., M. Praag and A. Ijsselstein, 2010. The impact of entrepreneurship education on entrepreneurship skills and motivation. Eur. Econ. Rev., 54: 442-454. DOI: 10.1016/j.euroecorev.2009.08.002

Patton, M.Q., 2002. Qualitative Research and Evaluation Methods. 3rd Edn., Sage Publications, Inc., Newbury Park, CA., ISBN: 10: 0761919716 , pp: 598 .

Pittaway, L. and J. Cope, 2007a. Entrepreneurship education: A systematic review of the evidence. Int. Small Bus. J., 25: 479-510. DOI: 10.1177/0266242607080656

Pittaway, L. and J. Cope, 2007b. Simulating entrepreneurial learning: Integrating experiential and collaborative approaches to learning. Manage. Learn., 38: 211-233. DOI: 10.1177/1350507607075776

Pittaway, L., P. Hannon, A. Gibb and J. Thompson, 2009. Assessment practice in enterprise education. Int. J. Entrepreneurial Behav Res., 15: 71-93. DOI: 10.1108/13552550910934468

Rae, D. and M. Carswell, 2000. Using a life-story approach in researching entrepreneurial learning: The development of a conceptual model and its implications in the design of learning experiences. Education + Training, 42: 220-228. DOI: $10.1108 / 00400910010373660$
Sambasivan, M., M. Abdul and Y. Yusop, 2009. Impact of personal qualities and management skills of entrepreneurs on venture performance in Malaysia: Opportunity recognition skills as a mediating factor. Technovation, 29: 798-805. DOI: 10.1016/j.technovation.2009.04.002

Segal, G., D. Borgia and J. Schoenfeld, 2005. The motivation to become an entrepreneur. Int. J. Entrepreneurial Behav. Res., 11: 42-57. DOI: 10.1108/13552550510580834

Smith, A.J., L.A. Collins and P.D. Hannon, 2006. Embedding new entrepreneurship programmes in UK higher education institutions: Challenges and considerations. Education + Training, 48: 555-567. DOI: 10.1108/00400910610710001

Souitaris, V., S. Zerbinati and A. Al-Laham, 2007. Do entrepreneurship programmes raise entrepreneurial intention of science and engineering students? The effect of learning, inspiration and resources. J. Bus. Vent., 22: 566-591. DOI: 10.1016/j.jbusvent.2006.05.002

Surie, G. and A. Ashley, 2008. Integrating pragmatism and ethics in entrepreneurial leadership for sustainable value creation. J. Bus. Ethics, 81: 235246. DOI: 10.1007/s10551-007-9491-4

Swiercz, P.M. and S.R. Lydon, 2002. Entrepreneurial leadership in high-tech firms: A field study. Leadership Org. Dev. J., 23: 380-386. DOI: 10.1108/01437730210445810

Wayne, P.L., L.L. Plumly, J. Marshall, R. Iyer and J. Eastman et al., 2008. Developing entrepreneurial competencies: A student business. J. Entrepreneurship Educ.

Wilson, F., J. Kickul and D. Marlino, 2007. Gender, entrepreneurial self-efficacy and entrepreneurial career intentions: Implications for entrepreneurship education. Entrepreneurship Theory Practice, 31: 387-401. DOI: 10.1111/j.1540-6520.2007.00179.x

$\mathrm{Wu}, \mathrm{S}$. and L. Wu, 2008. The impact of higher education on entrepreneurial intentions of university students in China. J. Small Bus. Dev., 15: 752-774. DOI: 10.1108/14626000810917843

Zampetakis, L.A., 2008. The role of creativity and proactivity on perceived entrepreneurial desirability. Thinking Skills Creativ., 3: 154-162. DOI: 10.1016/j.tsc.2008.07.002

Zhao, H., S.E. Seibert and G.E. Hills, 2005. The mediating role of self-efficacy in the development of entrepreneurial intentions. J. Applied Psychol., 90: 1265-1272. DOI: $10.1037 / 0021-$ 9010.90 .6 .1265 